\title{
INFESTATION OF MAJOR PESTS AND DISEASES ON VARIOUS CASSAVA CLONES IN LAMPUNG-INDONESIA
}

\author{
I Gede Swibawa ${ }^{1}$, Franciscus Xaverius Susilo ${ }^{1}$, Purnomo ${ }^{1}$, Titik Nur Aeny ${ }^{1}$, \\ Setyo Dwi Utomo ${ }^{2}$ \& Erwin Yuliadi
}

\author{
${ }^{1}$ Department of Plant Protection, Faculty of Agriculture, University of Lampung, Indonesia \\ ${ }^{2}$ Department of Agronomy and Horticulture, Faculty of Agriculture, University of Lampung, Indonesia \\ Jl. Prof. Sumantri Brodjonegoro No. 1 Bandar Lampung 35145 \\ E-mail : igede.swibawa@fp.unila.ac.id
}

Manuscript received: 21 December 2019. Revision accepted: 10 February 2020

\begin{abstract}
Infestation of major pests and diseases on various cassava clones in Lampung-Indonesia. Lampung Province is one of cassava producers in Indonesia which contributes more than 30\% to the total national cassava production. However, the infestation of pests and diseases can limit cassava production in the field. The objective of this research was to observe the infestation level of major plant pests and diseases of cassava in Lampung. A survey was conducted in August 2016 in several locations of cassava fields owned by farmers and experimental plots in the area of Faculty of Agriculture, University of Lampung. The results showed that cassava mealybug (Phenacoccus manihoti), papaya mealybug (Paracoccus marginatus) and red mite (Tetranychus urticae) infested at cassava clones in Lampung. The infestation of red mite tended to be higher than that of mealybugs. The cassava brown leaf spot disease that infested in mild to moderate severity was found on all cassava clones, while viral disease with prevalence of $78 \%$ was only found on Duwet 1 clone in experimental plot.
\end{abstract}

Key words: cassava, leaf spot diseases, mealybugs, red mite

\section{INTRODUCTION}

Lampung Province contributes more than $30 \%$ to national cassava production in Indonesia. In 2013, the total production of cassava in Indonesia was around 23 million ton with 1 million ha of planting area, while the total production and planting area of cassava in Lampung were 8 million ton and 0.3 million ha, respectively (BPS, 2014). Indonesian Government encourages expansion of cassava plantation later; because the area of this crop tends to decline (Kementerian Pertanian, 2016).

The expansion of cassava cropping systems are usually followed by an increase in pests and diseases problem. According to Bellotti (2002), there were around nine pest species infested cassava in Asia, including spider mite, mealybugs, whitefly, scale insect, fruit fly, grubs, termites, and stem borer. They were considered as serious problem in many cassava producing countries. Abaca et al. (2014) reported that green mite, mosaic wilt and cassava wilt bacteria were the main pests and diseases in Northwest of Uganda. The green mite infestation reached 37-100 \%. In Ivory Coast, the mites is also reported capable to spread in a very wide area every year (Yaninek et al., 1989). Other pest such as whitefly (Bemisia tabaci) is reported as a vector of mosaic geminivirus disease on cassava that causes crop yield loss of more than 1.5 million USD in Africa (Ewusie et al., 2010).

Spider mites and mealybugs are also reported as the major pest of cassava in Indonesia. According to Kalshoven (1981), the spider mite species attacking cassava in Indonesia was Tetranychus bimaculatus (synonym: T. urticae), while Astuti (2014) also found that $T$. kanzawai can reduce $95 \%$ of cassava production in West Java. Papaya mealybug and cassava mealybug are two important species attacking cassava in Indonesia. Muniappan et al. (2009) described that cassava mealybug (Phenacoccus manihoti) was a very destructive pest. Cassava mealybug and papaya mealybug (Paracoccus marginatus) were exotic pests that have been entering Indonesia since 2007 (Wardani, 2015). Infestation of the two mealybug species on young crops of cassava caused bunchy top symptoms, stunting, followed by dropping leaves and reduced $40-50 \%$ of production. Based to CLIMAX model, Parsa et al. (2012) predicted that cassava mealybug (P. manihoti) risk is most acute in the southern end of Karnataka in 
India, the eastern end of the Ninh Thuan Province in Vietnam, and in most of West Timor in Indonesia, because of climate suitability.

There are many clones of cassava cultivated by farmer in Lampung, but the two most dominant clones were UJ-3 and UJ-5. The characteristic of the clones was high production and high starch content within tubers. Infestation of pests and diseases can limit the production of cassava in Lampung, but information about the pests and disease infestation is still lacking. The objective of this research was to observe the infestation level of major pests such as mealybug, red mite and major diseases especially leaf spot disease on cassava from several cassava fields in Lampung-Indonesia.

\section{MATERIALS AND METHODS}

Research Site. Sampling of pests and diseases were conducted from May to August 2016 on two types of cassava field, the first was owned by farmers and the second was cassava plot in Experimental Station of Faculty of Agriculture, University of Lampung. The cassava fields was distributed in several locations, i.e. Bandar Lampung, South Lampung, and East Lampung Districts. At least 20 clones of cassava were planted in the experimental plots. Samples were processed in the Laboratory of Plant Pests and Diseases, University of Lampung-Indonesia.

Two ha of cassava plantation area was selected as sampling site for each location. Within a sampling site, 10 subsample rows in 3-row intervals were taken systematically across the field diagonal. One subsample row consisted of 10 plants. The prevalence of mealybug, spider mites and brown leaf spot disease were documented in each subsample. The disease severity was grouped into four categories, i.e. healthy, mild, moderate and severe, respectively. The pest infestation and disease incidence were measured by the following formula:

$$
\text { Pest infestation }=\frac{\text { number of infested plants }}{\text { total number of plants observed }} \times 100 \%
$$

Disease incidence $=\frac{\text { number of diseased plants }}{\text { total number of plants observed }} \times 100 \%$

Mealybug and spider mite population were measured from the leaves of five cassava plants that were taken randomly. From each plant sample, six leaves were taken respectively from the lower and middle part of plant. The pests on the leaves were counted using a hand-tally counter under a stereo binocular microscope (LEICA EZ4HD) in laboratory. The counting unit is the basal area of cassava leaf within $2 \mathrm{~cm}$ radius (leaf base).

\section{RESULTS AND DISCUSION}

The major pests found infesting cassava in Lampung were red spider mite (Tetranychus spp., Acarina: Tetranychidae), and two species of mealybugs: the cassava mealybug (Phenacoccus manihoti MatileFerrero, Hemiptera: Pseudococcidae) and the papaya mealybug (Paracoccus marginatus Williams and Granada de Willink, Hemiptera: Pseudococcidae). The major disease was the brown cassava leaf spot caused by fungi Cercospora henningsii. Figure 1 shows that the pests infesting cassava plants in all locations surveyed. The infestation of red mite tended to be higher than that of mealybugs in all locations, except in Sukarame area. The infestation of mealybugs in NTF-1 area and NTF-2 area tended to be lower than in other

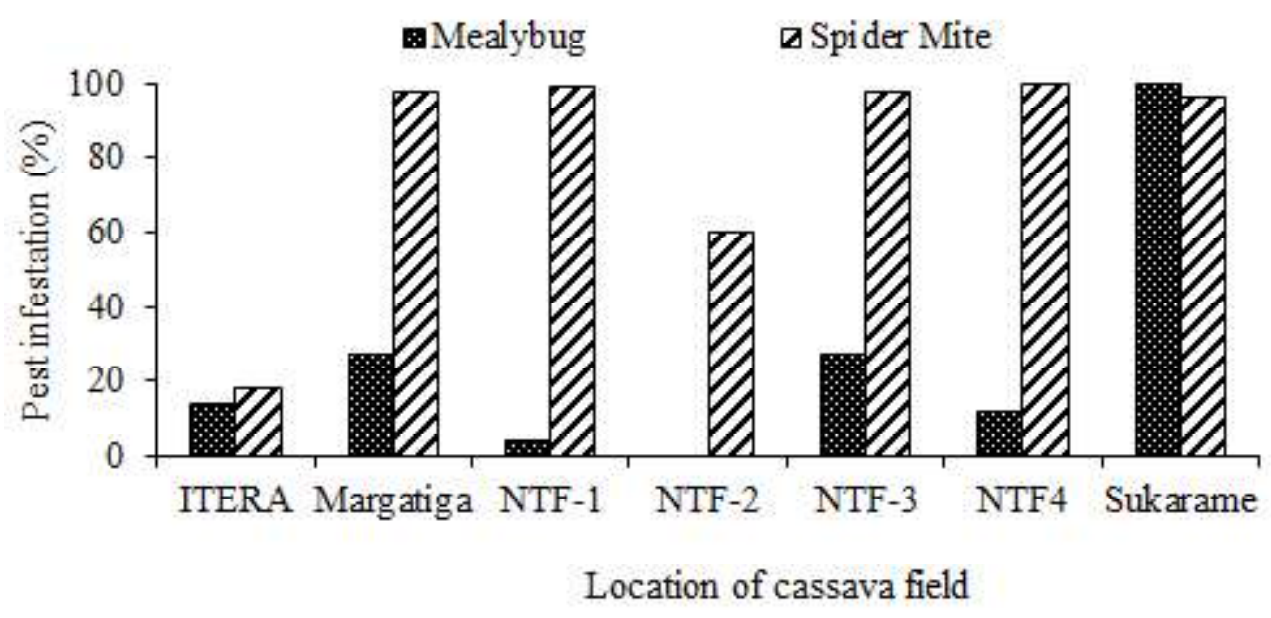

Figure 1. The prevalence of spider mite and mealybug infestation on several cassava field in Lampung, Indonesia. 
locations. The brown leaf spot disease was found in all surveyed locations with disease severity from mild to severe, while the moderate to severe category occurred on cassava in NTF-1 area and NTF-3 area. The mild category of diseases occurred in the other locations (Figure 2).

Based on leaf position, the mealybugs preferred to attack on both the lower and middle leaves, while red spider mite preferred to attack on the middle leaves. The population of mealybugs on the lower versus middle leaves was not different, but the population of red mite was higher on the middle leaves (Figure 3 ).

Pest population and disease prevalence on various cassava clones were depicted in Table 1. In general, the population density of spider mites and mealybugs on various cassava clones was low. The highest mealybug population that reached nine individuals per leaf base was found on clone UJ3 (1), while the pest population on the other 19 clones were around two or less individuals per leaf base. The spider mite population on these various clones was also low. The population mean of the pests on four cassava clones, namely Baris 14, Baris 17, Gajah and SL 75 were 2 individuals per leaf base and tended to be higher than that on the other 16 clones. The lower population of mealybugs and red mite in this study may due to climate condition was not vaporable to the pest. Observation of pest was conducted at May, when season was rainy. The severity of the brown leaf spot disease on all cassava clones were mild to moderate, but the disease prevalance was

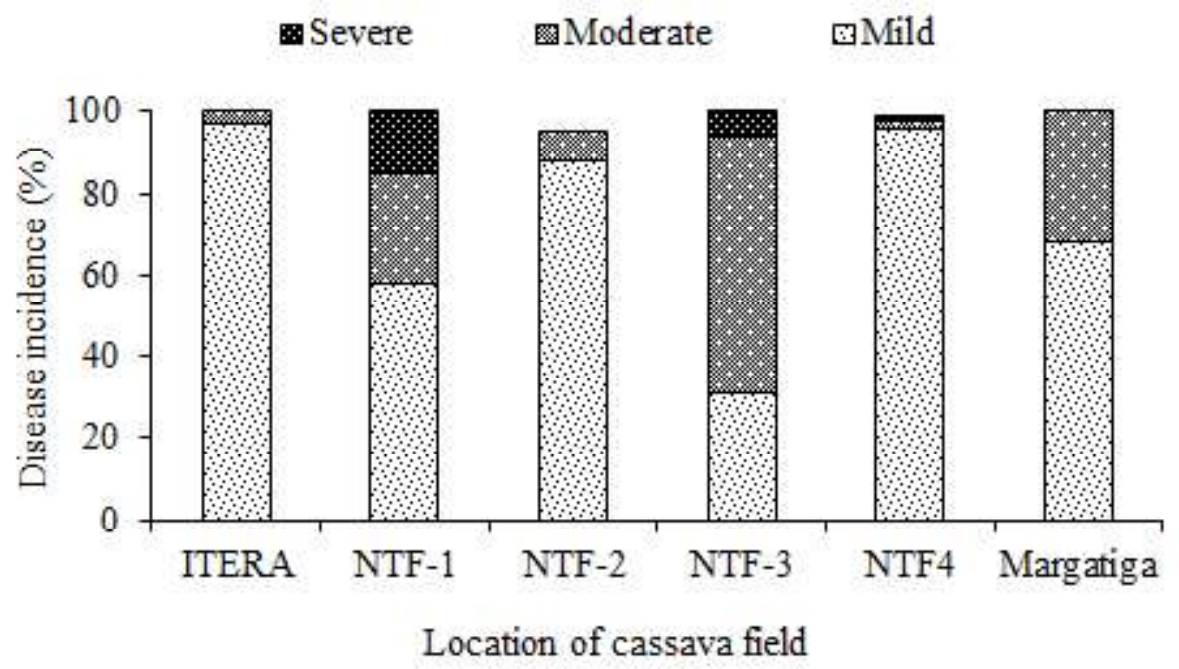

Figure 2. Brown leaf spot prevalence in several cassava fields in Lampung, Indonesia.
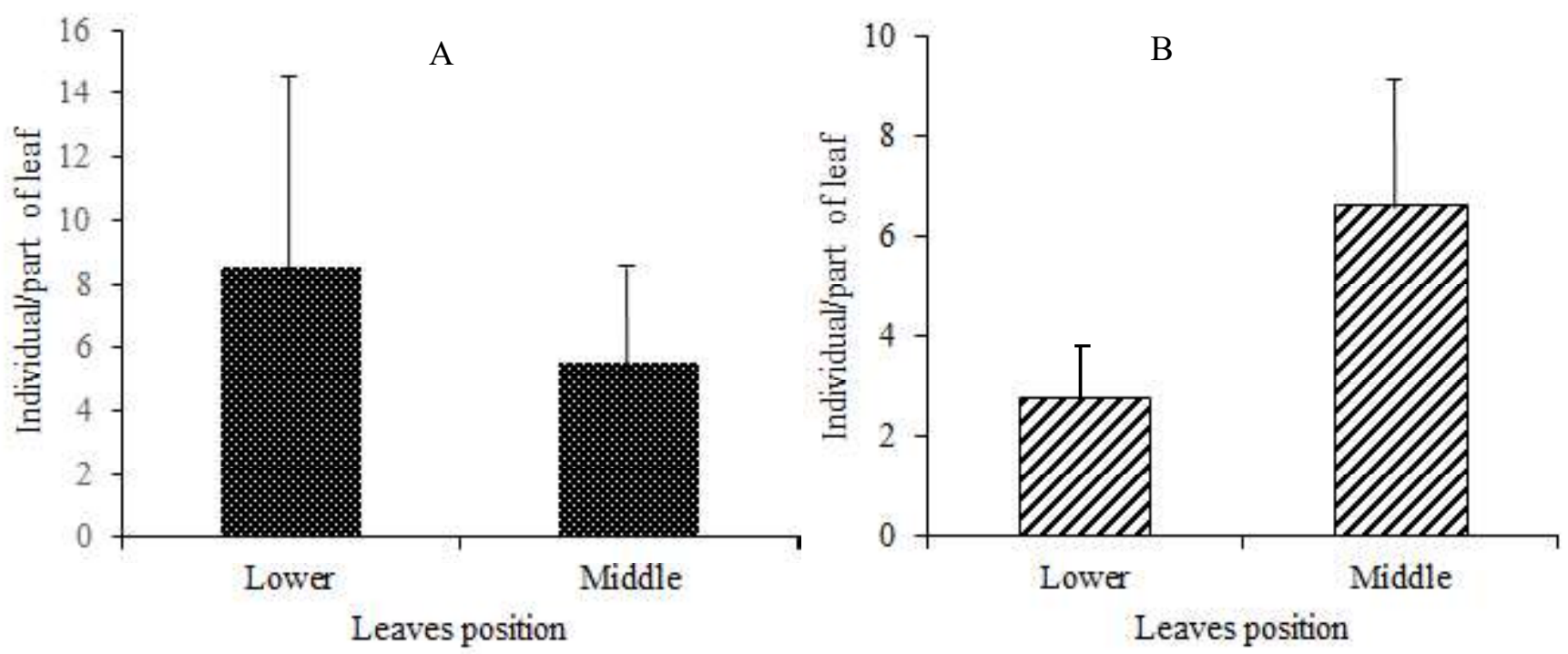

Figure 3. Population density of pest on lower and middle cassava leaves. (A) Mealybug, (B) Mite. 
high. Most clones showed 100\% disease prevalence and on the rest ranged $40-80 \%$ prevalence. Two clones, namely SL75 and T45 showed 100 and 66\% prevalence with moderate severity, respectively, while clones Cimanggu Pekalongan, Adira 4 Baturaja, CMM 97-(17), UJ5 22-11-2014, 17, UJ3(1), Baris 14, Gajah, and Baris 17 showed $100 \%$ prevalence with mild disease severity. The rest of the clones showed mild and moderate severity. Viral disease on cassava with dwarf, small leaves and curly symptoms were found on several clones, namely T45, UJ5 22-11-2014, UJ3(1), Baris 14, UJ4 Masgar, MU III, Baris 20, and Duwet 1. The disease prevalence on Baris 20 and Duwet 1 clones was more than $70 \%$.

Mealybugs, red mite and brown leaf spot were found to infest all observed cassava clones in Lampung, Indonesia. The mealybugs often found were cassava mealybug (Phenacoccus manihoti) and papaya mealybug (Paracoccus marginatus), while the red mite was Tetranychus urticae. This data indicated that the two species of mealybugs and the red mite were the major pests of cassava in Indonesia especially in Lampung Province. The cassava mealybug infested cassava plants in West Java, Indonesia since 2007 (Wardani, 2015). Muniappan et al. (2009), also reported that $P$. manihot $i$ was a new invasive species attacking cassava in Indonesia. Sartiami et al. (2014) reported that the mealybugs were also found in Malaysia. Yonow et al. (2017) indicated that $P$. manihoti have been spreading to Indonesia. The polyphagia of papaya mealybug was the first record in Indonesia in 2008 (Muniappan at al., 2008). Papaya mealybugs attacked 32 plant genera including papaya and cassava which was in severe category (Susilo et al., 2009). The attacks of Phenacoccus manihoti and Paracoccus marginatus in cassava are usually undistinguishable, so farmers assume that the two mealybugs are the same species.

The finding of this research indicated that the major pests of cassava in Indonesia especially in Lampung are comparable with cassava pests in Africa and other regions. According to Abaca et al. (2014),

Table 1. Population density of pests and diseases prevalence on several cassava clones surveyed in LampungIndonesia

\begin{tabular}{|c|c|c|c|c|c|c|}
\hline \multirow{3}{*}{ Cassava clones } & \multirow{2}{*}{ Spider mites } & \multirow{2}{*}{ Mealybugs } & \multicolumn{3}{|c|}{ Brown leaf spot disease } & \multirow{3}{*}{ Viral disease } \\
\hline & & & Mild & Moderate & Severe & \\
\hline & \multicolumn{2}{|c|}{ Indiv/leaf part } & \multicolumn{3}{|c|}{$\%$} & \\
\hline GM 1 & 0.50 & 0.20 & 80.00 & 20.00 & 0.00 & 0.00 \\
\hline Cimanggu Pekalogan & 1.17 & 0.11 & 85.71 & 0.00 & 0.00 & 0.00 \\
\hline SL 75 & 2.00 & 0.44 & 0.00 & 100.00 & 0.00 & 0.00 \\
\hline Adira 4 Baturaja & 0.72 & 0.56 & 100.00 & 0.00 & 0.00 & 0.00 \\
\hline UJ5 & 1.42 & 0.88 & 75.00 & 25.00 & 0.00 & 0.00 \\
\hline UJ3 & 0.50 & 0.39 & 33.33 & 66.67 & 0.00 & 0.00 \\
\hline BL2 & 0.54 & 2.08 & 80.00 & 20.00 & 0.00 & 0.00 \\
\hline CMM 97- (17) & 0.40 & 0.90 & 100.00 & 0.00 & 0.00 & 0.00 \\
\hline T45 & 1.33 & 1.42 & 0.00 & 66.67 & 0.00 & 33.33 \\
\hline UJ5 22-11-2014 & 0.83 & 1.42 & 75.00 & 0.00 & 0.00 & 25.00 \\
\hline 17 & 1.17 & 1.10 & 100.00 & 0.00 & 0.00 & 0.00 \\
\hline UJ3 (1) & 0.53 & 8.83 & 100.00 & 0.00 & 0.00 & 50.00 \\
\hline Baris 14 & 1.69 & 0.28 & 75.00 & 0.00 & 0.00 & 25.00 \\
\hline Gajah & 1.54 & 0.04 & 100.00 & 0.00 & 0.00 & 0.00 \\
\hline UJ3 Masgar & 0.31 & 1.92 & 44.44 & 11.11 & 0.00 & 44.44 \\
\hline Baris 17 & 1.88 & 2.71 & 100.00 & 0.00 & 0.00 & 0.00 \\
\hline Cimanggu & 0.10 & 2.03 & 87.50 & 12.50 & 0.00 & 0.00 \\
\hline MU III & 0.07 & 2.27 & 80.00 & 20.00 & 0.00 & 60.00 \\
\hline Baris 20 & 0.23 & 1.40 & 42.86 & 57.14 & 0.00 & 71.43 \\
\hline Duwet 1 & 0.13 & 1.70 & 77.78 & 22.22 & 0.00 & 77.78 \\
\hline
\end{tabular}


the main pests of cassava in Africa were cassava mealybug ( $P$. manihoti), African root scale insect (Stictococcus vayssierei) and cassava green mite (Mononychelus tanajoa). Bellotii (2002) also described nine species of pests that attack cassava in Asia, including mite, mealybugs, whitefly, fruit fly, grubs, termite, and stem borer. The other pests as mentioned by Bellotii (2002), are considered to be a minor pest of cassava in Lampung, so they were not recorded in this study.

Mealybugs and red spider mites were found in all cassava locations observed in Lampung, including in the experimental plot of Faculty of Agriculture, University of Lampung in Natar area (Figure 1, and Table 1). The data indicated that mealybugs and red mites spread in almost all locations in Lampung. Even though mealybugs and mites were unable to move for long distance, the pest was able to disperse by wind and plant material transportation from island to island. Yaninek et al. (1989) reported that green mite was able to spread $600 \mathrm{~km}$ per year in Ivory Coast. The papaya mealybug (P. marginatus) was firstly reported in Bogor- West Java in 2008, then it was found in Lampung in 2009 infesting many plants species including cassava (Susilo et al., 2009).

The prevalence of mealybug and red spider mite were high in all locations and clones (Figure 1), but their population number were low (Table 1). This result was consistent with Indiati (2012) that reported all early maturing cassava clones attacked by red mite were high in the prevalence but low in population number, so there were not effects on production. In addition, mealybug attacked at all leaves position, but spider mite attacked at the middle old leaves. Wardani (2015) described that bunchy top or stunning symptoms of cassava were caused by cassava mealybugs, and the pest attack on young plant will reduce $40-50 \%$ of production.

Brown leaf spot (Cercospora henningsii) disease was found infesting all cassava plants while mosaic virus disease was also found in small Experimental Plot of Faculty of Agriculture, University of Lampung in Natar, Lampung. The result of this study was different from previous reports of cassava diseases in Indonesia and other countries. Sundari (2010) reported that cassava diseases in Indonesia were mostly caused by bacteria and fungi. Abaca et al. (2014) reported that cassava in Africa was attacked by four diseases, namely, cassava mosaic diseases (CMD), cassava brown streak disease (CBSD), cassava bacterial blight (CBB) caused by Xanthomonas axonopodis pv. manihotis while cassava anthracnose caused by Colletotrichum gloeosporioides (CA). The differences in finding of the diseases in this study with the previous report may be cause of the differences of clone of cassava or climate condition between Indonesia and Africa.

Brown leaf spot and mosaic virus diseases were found in this observation. The brown leaf spot disease was found in all locations of cassava fields (Figure 2) and cassava clones (Table 1). Batino et al. (2007) also reported that brown leaf spot incidence were high (ranged 68-100\%) in all cassava growing areas. That mosaic virus disease was only found in Experimental Plot in Natar area indicated that this disease did not widespread yet in Lampung. According to Ewusie et al. (2010), mosaic virus disease of cassava in Africa was transmitted by whitefly (Bemisia tabaci). In this study, the vector that transmited the viral-disease was still not clear because no whitefly found in this study. In our opinion the mealybug associated with the cassava plants can act as a vector transmitted of the mosaic virus.

\section{CONCLUSION}

The pests of cassava plants in Lampung were dominated by cassava mealybug (P. manihoti), papaya mealybug ( $P$. marginatus) and red spider mite (T. urticae). The pests infested in almost all cassava clones in various locations surveyed in Lampung, Indonesia. The prevalence of red mite infestation that reached $100 \%$ in five locations tended to be higher than that of mealybugs that around $5-30 \%$ in the five locations. The cassava diseases found were brown leaf spot and mosaic virus disease. Brown leaf spot infestation in mild and moderate severity was found on all cassava clones and locations, while the viral disease with prevalence of $78 \%$ was only found on clone Duwet 1 in the experimental plot. It still needs a further study to find out whether the environmental factors and agronomic practices influence the cassava pests and diseases infestation in Lampung.

\section{ACKNOWLEDGMENT}

This research was partially supported by the Indonesian National Strategic Research Grant (Hibah Strategis Nasional) of the Ministry of Research, Technology, and Higher Education (Kemenristekdikti) (Letter of Appointment from the Head, University of Lampung Research Institute No. 419/UN26/8/LPPM/ 2016). Faculty of Agricultural, University of Lampung also funded this research. The authors appreciate and thank for the financial support. 


\section{REFERENCES}

Abaca A, Kiryowa M, Awori E, Andema A, Dradiku F, Moja AS, \& Mukalazi J. 2014. Cassava pests and diseases' prevalence and performance as revealed by adaptive trial sites in North Western Agro-Ecological Zone of Uganda. J. Agric. Sci. 6(1): 116-122.

Astuti W. 2014. Ketahanan Empat Kultivar Ubikayu terhadap Tetranychus kanzawai Kishida (Acari: Tetranichidae). Skripsi. Institut Pertanian Bogor, Bogor.

Banito A, Verdier V, Kpémoua KE, \& Wydra K. 2007. Assessment of major cassava diseases in Togo in relation to agronomic and environmental characteristic in a systems approach. Afr. $J$. Agric. Res. 2(9): 418-428.

Bellotti AC. 2002. Artropods pest. In: Hillocks RJ, Thresh JM, \& Bellotti AC (Eds.). Cassava: Biology, Production and Utilization. pp. 209-235. CABI publishing, Wallingford.

BPS. 2014. Produksi Ubikayu Nasional. https:// www.bps.go.id/dynamictable/2015/09/09/880/ produksi-ubi-kayu-menurut-provinsi-ton-19932015.html. Accessed on 23 November 232017.

Ewusie EA, Parajulee MN, Adabie-Gomez DA, \& Wester D. 2010. Strip Cropping: a potential IPM tool for reducing whitefly, Bemisia tabaci Gennadius (Homoptera: Aleyrodidae) infestation in cassava. West Afr. J. Appl. Ecol. 17: 100119.

Indiati SW. 2012. Ketahanan varietas/klon ubikayu umur genjah terhadap tungau merah. Penelitian Pertanian Tanaman Pangan. 31(1): 53-59.

Kalshoven LGE. 1981. The Pests of Crops in Indonesia (revised by Van der Laan). PT. Ichtiar Baru, Van Hoeve, Jakarta.

Kementerian Pertanian. 2016. Outlook Komoditas Pertanian Sub Sektor Tanaman Pangan: Ubi kayu. Pusat Data dan Sistem Informasi Pertanian. Kementerian Pertanian, Jakarta.

Muniappan R, Shepard BM, Watson GW, Carner GR, Sartiami D, Rauf A, \& Hammig MD. 2008. First report of the papaya mealybug, Paracoccus marginatus (Hemiptera: Pseudococcidae), in Indonesia and India. J. Agric. Urban Entomol. 25(1): 37-40.
Muniappan R, Shepard BM, Watson GW, Carner GR, Rauf A, Sartiami D, Hidayat P, Avun JVK, Georgen G, \& Rahman AKMZ. 2009. New records of invasive insects (Hemiptera: Sternorrhyncha) in Southeast Asia and West Africa. J. Agric. Urban Entomol. 26(4): 167174.

Parsa S, Kondo T, \& Winotai A. 2012. The cassava mealybug (Phenacoccus manihoti) in Asia: first records, potential distribution, and an identification key. PLoS ONE. 7(10): e47675.

Sartiami D, Watson GW, Roff MNM, Hanifah MY, \& Idris AB. 2014. First record of cassava mealybug, Phenacoccus manihoti (Hemiptera: Pseudococcidae), in Malaysia. Zootaxa. 3957(2): 235-238.

Sundari T. 2010. Pengenalan varietas unggul dan teknik budidaya ubikayu. Materi Pelatihan Agribisnis bagi KMPH. Balai Penelitian Kacang Kacangan dan Umbi Umbian, Malang.

Susilo FX, Purnomo, \& Swibawa IG. 2009. Infestation of the papaya mealybug in home yard plants in Bandar Lampung, Indonesia. In: Lumbanraja J, Susilo FX, Purnomo, Hasibuan R, Niswati A, Yusnaini S, Hori H, \& Okazaki K (Eds.). Proceeding of the $3^{\text {rd }}$ International Meeting for the Development of IPM in Asia and Africa, Bandar Lampung, Indonesia. pp. 81-92. University of Lampung Press, Bandar Lampung.

Wardani N. 2015. Kutu putih ubi kayu, Phenacoccus manihoti Matile-Ferrero (Hemiptera: Pseudococcidae), hama invasif baru di Indonesia. Disertasi. Institut Pertanian Bogor, Bogor.

Yaninek JS, de Moraes GJ, \& Markham RH. 1989. Handbook on the Cassava Green Mite (Mononychellus tanajoa) in Afrika. International Institute of Tropical Agriculture, Ibadan.

Yonow T, Kriticos DJ, \& Ota N. 2017. The potential distribution of cassava mealybug (Phenacoccus manihoti), a threat to food security for the poor. PLOS ONE. 12(3): e0173265. 